\title{
Influence of starter and adjunct lactobacilli culture on ripening of miniature washed-curd cheeses
}

\author{
Erica HYNES ${ }^{\mathrm{a}}$, Jean-Claude OGIER ${ }^{\mathrm{b}}$, Olivier SON ${ }^{\mathrm{b}}$, Agnès DELACROIX-BUCHET ${ }^{\mathrm{b} *}$ \\ a Facultad Ingenieria Quimica, Santiago del Estero 2829, (3000) Santa Fe, Argentina \\ b Unité de Recherches Laitières et Génétique Appliquée (URLGA), INRA, Domaine de Vilvert, 78352 , \\ Jouy-en-Josas Cedex, France
}

(Received 16 July 2001; accepted 26 April 2002)

\begin{abstract}
Ten strains of Lactobacillus were tested as adjunct cultures in combination with two different Lactocococcus lactis starters in miniature washed-curd cheeses manufactured under controlled bacteriological conditions. Growth of lactobacilli seemed to depend on the strain used, but was not influenced by the starter strain (either L. lactis subsp. lactis IL416 or L. lactis subsp. cremoris AM2). Lactococcal counts in miniature cheeses with AM2 starter and added lactobacilli were higher than in control cheeses without lactobacilli. Consistently good survival ( 100\% after four weeks) was observed for IL416, regardless of the presence of adjunct culture). In contrast, AM2 starter cell viability decreased slowly over the same time period. Gross composition and protein analyses were performed on the miniature cheeses. Our results indicate that production of soluble nitrogenous compounds was influenced by the lactobacilli adjunct, and depended on the starter strain. We conclude that the use of different combinations of starter and adjunct cultures can result in marked differences in bacterial populations and product properties. Such studies may be used to choose the combination of strains necessary to obtain a product with particular properties.
\end{abstract}

\section{Lactobacilli adjunct culture / starter / proteolysis / cheese}

Résumé - Influence du levain et d'une culture secondaire de lactobacilles sur l'affinage des fromages miniatures type pâte pressée. Dix souches de lactobacilles de la collection CNRZ ont été testées en tant que culture secondaire, en combinaison avec deux souches différentes de levain Lactococcus lactis, dans des fromages miniatures type pâte pressée fabriqués en conditions bactériologiques contrôlées. La croissance des lactobacilles semble dépendre de la souche utilisée, mais elle n'est pas influencée par la souche de levain (L. lactis subsp. lactis IL416 ou L. lactis subsp. cremoris AM2). La numération des lactocoques dans les fromages miniatures fabriqués avec la souche AM2 et addition de lactobacilles est plus élevée que dans les fromages témoins sans ajout de lactobacilles. Comme attendue, une bonne survie a été observée pour IL416 ( 100\% après quatre semaines), et ce indépendamment de la présence d'une culture secondaire. Au contraire, la viabilité de AM2 a décru au cours de la même période. La composition globale et des analyses biochimiques ont été réalisées sur les fromages miniatures. Nos résultats indiquent que l'addition de lactobacilles influence la production de composés azotés solubles en liaison avec la souche de

* Correspondence and reprints

Tel.: 331346520 92; fax: 331346520 65; e-mail: delacroi@jouy.inra.fr 
levain. Nous concluons qu'en utilisant différentes combinaisons de lactocoques et de cultures secondaires, on peut obtenir des différences marquées dans les populations bactériennes et les propriétés des produits. De telles études pourraient être utilisées pour choisir les combinaisons de souches nécessaires pour obtenir un produit avec des propriétés spécifiques.

\section{Culture secondaire de lactobacilles / levain / protéolyse / fromage type pâte pressée}

\section{INTRODUCTION}

Cheese ripening is a complex process involving proteolysis, lipolysis and metabolism of residual lactose, citrate and lactate [11]. These transformations are produced by enzymes of micro-organisms as well as residual chymosin and indigenous milk proteases (and lipases in raw-milk cheeses).

Starter lactic acid bacteria (LAB) ferment lactose to give lactic acid during cheese-making. They also play a role in cheese flavour development during ripening [10]. Starter bacteria are added at high concentrations to milk, and counts attain $10^{8}-10^{9} \mathrm{CFU} \cdot \mathrm{g}^{-1}$ after cheese manufacture; however, the bacteria die and lyse during ripening, at rates that vary from strain to strain [3]. The intracellular peptidases are then released into the curd, where they can hydrolyse peptides generated from primary proteolysis to free amino acids (FAA) [7]. Some amino acids are sapid compounds themselves, but FAA in cheese are mainly important as precursors of flavour, since LAB can metabolise them to ammonia, carbonyl and sulfur compounds, etc., all of which strongly influence cheese flavour [29]. Lactococci of the starter also participate in the metabolism of residual lactose, citrate and lactate to produce different volatile compounds that take part in cheese aroma [28]; they also show weak lipolytic activity [4].

The contribution to cheese ripening of the other important group of $\mathrm{LAB}$ in cheese, i.e. non-starter lactic acid bacteria (NSLAB), remains uncertain. In cheeses made with pasteurised milk, the adventitious NSLAB contaminate cheese after milk pasteurisation or survive the heat treatment [42]. The main source of contamination is probably the resident flora in the dairy plant and/or the raw milk itself [31]. In Cheddar cheese, adventitious NSLAB are able to grow from very low numbers to $10^{7}-10^{8} \mathrm{CFU} \cdot \mathrm{g}^{-1}$ during the first weeks of ripening, and dominate the cheese microflora after starter cell viability starts to decrease [11]. NSLAB are mainly mesophilic lactobacilli in cheeses made with pasteurised milk, but pediococci and enterococci have also been found $[6,29,32]$.

One strategy used to study the influence of NSLAB in ripening involves addition of Lactobacillus strains isolated from raw milk or cheese as a secondary or adjunct culture in cheese-making experiments. The majority of studies have shown that FAA content is increased and flavour intensity enhanced in experimental cheeses, even though acceptability by consumers is not always improved [2, 21, 23-25, 34]. Experimental Cheddar cheese containing a complex adjunct culture of mesophilic lactobacilli developed a stronger flavour than the control [30] and in another system, experimental cheese had a higher score for flavour intensity than the control [41]. Other authors have suggested that lactobacilli cultures can control the secondary microflora of cheese, and as such, prevent the growth of adventitious strains of NSLAB that may potentially cause defects [27]. However, these results are controversial: it was also reported that lactobacilli are not needed to obtain a good quality Gouda cheese [17] and the influence of lactobacilli in Cheddar cheese flavour was even suggested to be detrimental [43]. The influence of non-starter lactobacilli is suggested to be dependent on the species and strains composing this flora, and their final 
counts [33]. Furthermore, the starter strain and environmental factors (mainly temperature) seem to play a major role in secondary flora development [20].

Experimentation on cheese models for NSLAB study has proven to be complex. Even under the strict bacteriological conditions needed for cheese-making, control cheeses are susceptible to contamination by adventitious NSLAB, or the NSLAB may have survived pasteurisation $[2,17$, 41]. Phage attack, even at levels that do not compromise acidification, can also affect properties of the product by changing proteolysis patterns [3].

The objective of this work was to screen the expression (growth and biochemical activities) of ten adjunct cultures of mesophilic lactobacilli, during the ripening process of miniature washed-curd cheeses manufactured with two different Lactococcus starter strains in controlled microbiological conditions.

\section{MATERIALS AND METHODS}

\subsection{Cultures}

\subsubsection{Starter cultures}

Two types of starter cultures were used in the cheese-making: L. lactis subsp. lactis IL416, and L. lactis subsp. cremoris AM2.

Strain IL416 was selected for its high resistance to phage infection [5], and AM2 for its autolysis due to activated prophage [22]. Both strains were obtained from the CNRZ collection.

Each strain was inoculated in sterilised $\left(110{ }^{\circ} \mathrm{C}, 10 \mathrm{~min}\right)$, reconstituted $(10 \% \mathrm{w} / \mathrm{v})$, low-heat skim milk powder (Food Service, Le Pecq, France). Several ten-fold successive culture dilutions were prepared and incubated overnight at $25{ }^{\circ} \mathrm{C}$. The first dilution (in increasing order) in which milk did not clot was used as starter, to optimise the uniformity of starter activity and $\mathrm{pH}$ between cheese-making experiments.

\subsubsection{Adjunct cultures}

Five strains of $L b$. plantarum (identified as $1228,1245,1310,1311$ and 1572), one Lb. pentosus (1218) and four $L b$. casei $(1219,1227,1244$ and 1308) were tested as adjunct cultures. All the strains were obtained from the CNRZ collection (this laboratory), and had been isolated from cheese [38].

Strains were cultured individually in MRS broth [9] at $30{ }^{\circ} \mathrm{C}$ overnight, then transferred $(2 \%)$ and incubated for $8 \mathrm{~h}$ at $30{ }^{\circ} \mathrm{C}$. Several ten-fold dilutions were prepared and incubated at $30^{\circ} \mathrm{C}$ overnight. The dilutions with an optical density (O.D.) $=0.8$ (approximately $10^{8}$ to $5 \times 10^{8} \mathrm{CFU} \cdot \mathrm{mL}^{-1}$ for the tested strains) were used in the experiments.

\subsection{Cheese manufacture}

Two experimental cheeses (containing lactobacilli adjunct culture) and two control cheeses (without lactobacilli) of approximately $40 \mathrm{~g}$ each were produced simultaneously per cheese-making day. The choice of starter strains was alternated from one cheese-making day to another. Each lactobacilli adjunct was tested with both starters.

The cheeses were made in controlled bacteriological conditions, according to a previously described protocol adapted from Saint-Paulin type cheese technology $[13,36]$. Whole pasteurised homogenised pooled milk was purchased in the local market every two cheese-making days, and analysed for $\mathrm{pH}$, fat, dry matter, casein and non-protein nitrogen content to check for uniformity of gross composition.

Miniature cheeses were ripened for $28 \mathrm{~d}$ at $12{ }^{\circ} \mathrm{C}$ and $80 \%$ relative humidity. They were sampled for physical, chemical and microbiological analysis at 1,14 and $28 \mathrm{~d}$ of ripening. 


\subsection{Analyses}

\subsubsection{Gross composition of cheeses}

The $\mathrm{pH}$ values were determined throughout the cheese-making and ripening process with a $\mathrm{pH}$ meter Orion 920A (Orion, Boston, USA) equipped with a penetration electrode (Mettler Toledo, Paris, France). Measurements were taken on $2 \mathrm{~g}$ of milk or curd samples that were removed under sterile conditions.

Gross composition was determined on one-d-old cheeses. Dry matter was analysed in duplicate using the IDF method (IDF standard 4:1958) and $\mathrm{NaCl}$ content was determined in triplicate with a potentiometric chloride analyser (Corning Limited, Halstead, Essex, England).

\subsubsection{Bacteriological analyses and phage detection}

The population of starter lactococci present in the cheese products after 1,14 and $28 \mathrm{~d}$ of ripening was determined by plating sample dilutions on M17 agar and after $48 \mathrm{~h}$ of incubation at $30^{\circ} \mathrm{C}$ [39]. To determine the population of NSLAB, samples were also plated on Lactobacilli Selective Agar (LBS, Baltimore Biological Laboratories, Rockville, USA) and incubated for $72 \mathrm{~h}$ under anaerobic conditions [26]. The absence of lytic phages during cheesemaking was verified as described [16].

\subsubsection{Assessment of proteolysis}

Cheese samples were treated to obtain crude citrate extract, insoluble and soluble fractions at $\mathrm{pH} 4.4$ and the soluble fraction in phosphotungstic acid (PTA), according to Gripon et al. [12]. Nitrogen content of the fractions was determined in duplicate by the macro-Kjeldahl method according to the IDF Standard 20B [15].

The insoluble fraction at $\mathrm{pH} 4.4$ was analysed by reverse phase liquid chromatography (RP-HPLC) and the relation between the peak area for $\alpha$ s 1 casein and the peptide $\alpha s 1-\mathrm{I}$, resulting from chymosin activity, calculated as $\% \frac{\alpha_{\mathrm{s} 1}-\mathrm{I}}{\alpha_{\mathrm{s} 1-\mathrm{I}+\alpha_{\mathrm{s} 1}}}$ was used as an index of primary proteolysis. A $25 \mathrm{mg}$ casein sample was dissolved in $1.5 \mathrm{~mL}$ of a Bis-Tris buffer also containing urea and $\beta$-mercaptoethanol and analysed according to Visser et al. [44]. The HPLC equipment consisted of two pumps (models 501 and 510), an automatic injector Wisp 712, an interface module, and a model 484 Tunable Absorbance Detector (purchased from Waters: Millipore S.A., St. Quentin-en-Yvelines, France). A $250 \mathrm{~mm} \times 3.9 \mathrm{~mm}$ Nucleosil C18, $5 \mu \mathrm{m}-300 \AA$ analytical column was used (Macherey Nagel, Gmbh \& Co, Düren, Germany) with a C18 Bondapak cartridge as guard-column (Waters, St. Quentin-en-Yvelines, France). The chromatographic conditions were as described by Hynes et al. [14].

Ethanol $70 \%$ soluble extract of cheeses was also analysed by RP-HPLC using the equipment described above. The extract was prepared according to Lynch et al. [24]. Water-soluble extracts of the cheeses were obtained by blending $5 \mathrm{~g}$ of cheese and $15 \mathrm{~mL}$ of milliQ water with an Ultraturrax homogeniser (IKA-Werke, Gmbh \& Co, Düren, Germany) at maximum speed for 2 min then warmed up to $40{ }^{\circ} \mathrm{C}$ and maintained for $1 \mathrm{~h}$. The suspension was centrifuged at $3000 \mathrm{~g}$ and filtered through glass wool [18]. The filtered solution was adjusted to a final volume of $25 \mathrm{~mL}$, from which aliquots of $1 \mathrm{~mL}$ were fractionated by adding absolute ethanol to a final ethanol concentration of $70 \%(\mathrm{v} / \mathrm{v})$. For each sample, the mixture was maintained at room temperature for $1 \mathrm{~h}$ and micro-centrifuged at $12000 \mathrm{~g}$ for $10 \mathrm{~min}$. The supernatant was recovered and the ethanol was evaporated in a SpeedVac (Varian, Hicksville, USA). $120 \mu \mathrm{L}$ of each Speed-Vac-concentrated liquid sample were injected into the HPLC chromatograph. Detection was performed at $214 \mathrm{~nm}$ and the column temperature was $40^{\circ} \mathrm{C}$. 
Table I. Gross composition of control and experimental 1-d-old miniature cheeses. Dry matter and salt-in-moisture (S/M) means did not differ; $\mathrm{pH}$ was significantly different for the two starter strains $(P<0.05)$.

\begin{tabular}{lcc}
\hline Starter strain & IL416 & AM2 \\
\hline$\%$ Dry matter & $45.14 \pm 0.71$ & $44.92 \pm 0.76$ \\
$\%$ S/M & $2.45 \pm 0.21$ & $2.39 \pm 0.24$ \\
$\mathrm{pH}$ & $5.18 \pm 0.06$ & $5.08 \pm 0.05$ \\
\hline
\end{tabular}

The gradient, starting from $100 \%$ of solvent $\mathrm{A} \quad\left(\mathrm{H}_{2} \mathrm{O}\right.$-trifluoroacetic acid (TFA), 1000:1.1 v/v) and $0 \%$ of solvent $\mathrm{B}$ (Acetonitrile- $\mathrm{H}_{2} \mathrm{O}-\mathrm{TFA}$ 600:400:1 v/v/v), was generated $10 \mathrm{~min}$ after injection. The proportion of solvent $\mathrm{B}$ was increased at $1 \% \mathrm{~min}^{-1}$ (80 min); $20 \% \mathrm{~min}^{-1}$ (1 min); $0 \% \min ^{-1}(4 \mathrm{~min})$ and then returned to starting conditions, which took $1 \mathrm{~min}$. These last setting conditions were maintained for $10 \mathrm{~min}$.

Qualitative differences between peptide profiles of the ethanol $70 \%$ soluble extracts were evaluated by visually comparing chromatograms, and quantitative differences by comparing areas of individual peaks expressed as arbitrary area units.

\section{RESULTS}

\subsection{Gross composition}

The gross composition of the one-d-old miniature cheeses (Tab. I) successfully modelled washed-curd cheese varieties [35]. No significant differences in dry matter and salt-in-moisture (S/M) content were observed between starter strains. Average $\mathrm{pH}$ values were significantly lower for cheeses made with AM2 starter, than for those made with IL416 starter.

\subsection{Microbiology}

Bacterial cell counts of lactococci and lactobacilli were determined during ripening of cheeses prepared using the two tested starters with and without adjunct cultures (Figs. 1 and 2). The control cheeses were free of exogenous adventitious lactobacilli throughout the ripening period.

The bacterial counts of $L$. lactis IL416 remained constant during ripening (above $10^{9} \mathrm{CFU} \cdot \mathrm{g}^{-1}$ of cheese), indicating the good stability of the starter population. Lactobacilli did not dominate the microflora of the cheeses at any stage of ripening. For strains of $L b$. casei 1244 and 1308, and $L b$. pentosus 1218 , cell counts increased from $\sim 10^{6} \mathrm{CFU} \cdot \mathrm{mL}^{-1}$ in milk to $\sim 10^{7} \mathrm{CFU} \cdot \mathrm{g}^{-1}$ in curd during cheese-making and then remained constant. Lb. casei 1227 increased to $\sim 10^{8} \mathrm{CFU} \cdot \mathrm{g}^{-1}$ the first day and then remained constant. Lb. plantarum 1310, 1572 and 1245 populations all gained approximately $1 \log$ during ripening. The other strains did not increase during cheese-making (Fig. 1). Lactobacilli cells were added at circa $10^{6} \mathrm{CFU} \cdot \mathrm{mL}^{-1}$, but lactobacilli counts in 1-d-old cheeses were $\sim 10^{7} \mathrm{CFU} \cdot \mathrm{g}^{-1}$. This increase could be a consequence of cell concentration but also some growing that compensated for the loss of lactobacilli during whey removal and washing.

In contrast to IL416, the L. lactis AM2 population decreased $\sim$ hundred-fold during cheese ripening (to $10^{7} \mathrm{CFU} \cdot \mathrm{g}^{-1}$ ), possibly due to lysis by an activated prophage. Nevertheless, in several experimental cheeses (containing lactobacilli), the starter population remained higher than in control cheeses (without lactobacilli). This effect was verified for Lb. casei 1227 , 1244, 1308, Lb. plantarum 1572 and 1245 and $L b$. pentosus 1218 . It was suggested that lactococcal counts on M17 agar could be over-estimated in cheeses containing added lactobacilli [20]. This possibility was ruled out in our study because we observed that the tested Lactobacillus strains grew very slowly on M17 agar plates, and were not detected after $48 \mathrm{~h}$ of incubation under aerobic conditions. In addition, in experimental cheeses prepared with starter AM2 and Lactobacillus strains 1218 and 1572, lactobacilli counts were 

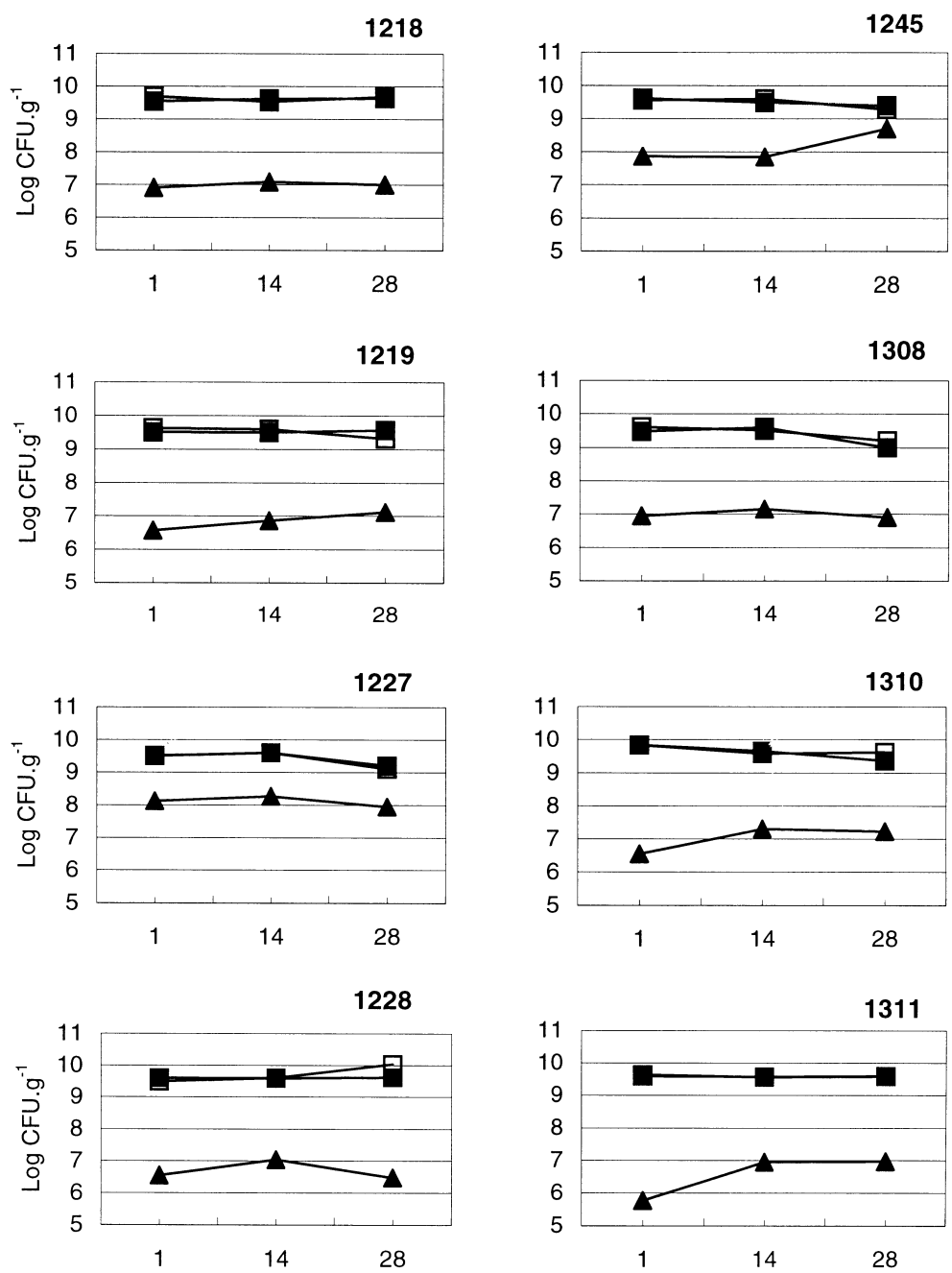

1244

1572
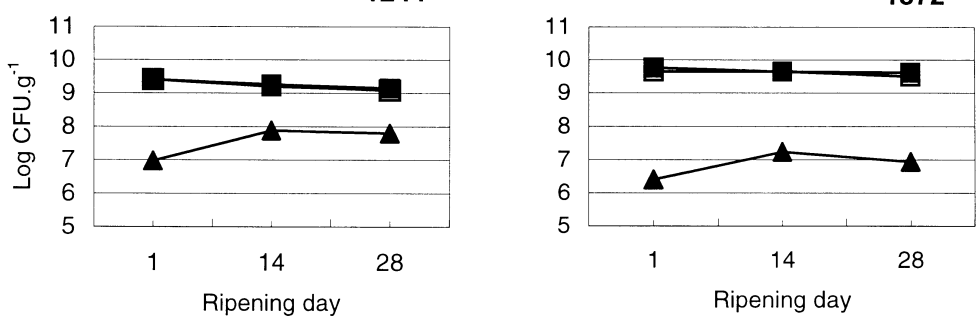

Figure 1. Growth curves of strain bacteria in miniature cheeses made with starter L. lactis IL416. $\square$ Lactococci in control cheese; $\square$ Lactococci in experimental cheese; $\Delta$ Lactobacilli in experimental cheese. Number in bold characters indicates Lactobacillus strain: $1218 \mathrm{Lb}$. pentosus; 1228, 1245, 1310, 1311 and 1572 Lb. plantarum; 1219, 1227, 1244 and 1308 Lb. casei. 

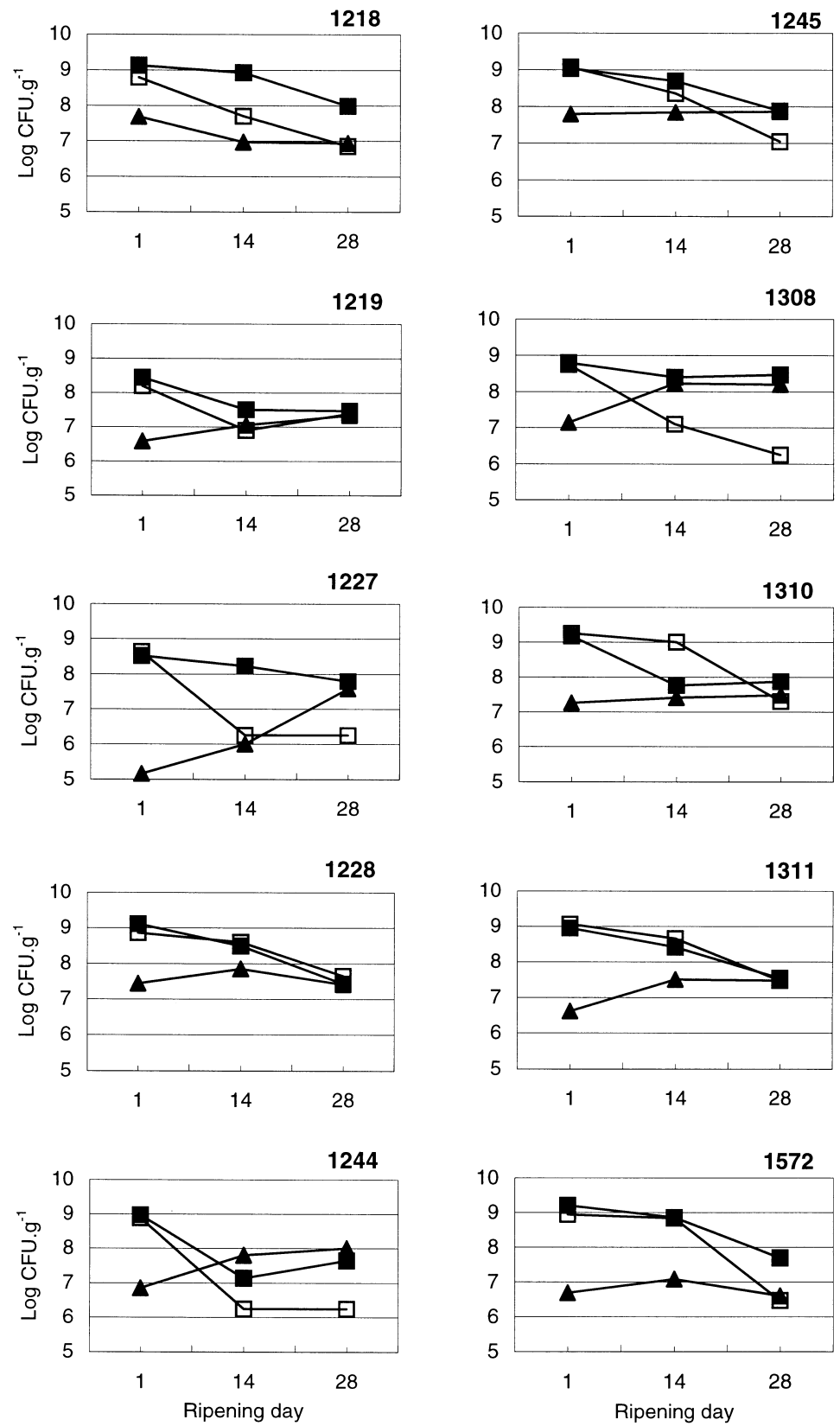

Figure 2. Growth curves of strain bacteria in miniature cheeses made with starter L. lactis AM2. $\square$ Lactococci in control cheese; $\square$ Lactococci in experimental cheese; $\Delta$ Lactobacilli in experimental cheese. Number in bold characters indicates Lactobacillus strain: $1218 \mathrm{Lb}$. pentosus; 1228, 1245, 1310, 1311 and 1572 Lb. plantarum; 1219, 1227, 1244 and 1308 Lb. casei. 
Table II. Index of primary proteolysis of control and experimental miniature cheeses at $28 \mathrm{~d}$ of ripening; means did not differ significantly $(P<0.05)$.

\begin{tabular}{|c|c|c|c|c|}
\hline Starter strain & \multicolumn{2}{|c|}{ IL416 } & \multicolumn{2}{|c|}{$\mathrm{AM} 2$} \\
\hline $\begin{array}{l}\text { Lactobacillus } \\
\text { adjunct }\end{array}$ & Without (control) & With (experimental) & Without (control) & With (experimental) \\
\hline$\% \frac{\alpha s 1-I}{\alpha s 1-I+\alpha s 1}$ & $37 \pm 4$ & $41 \pm 1$ & $43 \pm 3$ & $40 \pm 5$ \\
\hline
\end{tabular}

ten-fold lower than those of lactococci at 14 and $28 \mathrm{~d}$ of ripening, and were therefore negligible. That was also true for cheeses prepared with starter AM2 and Lactobacillus strains $1245,1227,1228$ and 1311 at $14 \mathrm{~d}$ of ripening (Fig. 2).

Lb. casei 1227 grew differently in miniature cheeses made with AM2 starter than in those made with IL416; in this context, CFU. $\mathrm{mL}^{-1}$ are at $\sim 10^{5}$ in one-dold cheese, and reach $\sim 10^{8} \mathrm{CFU} \cdot \mathrm{g}^{-1}$ at the end of the ripening period. Lb. casei 1308 was the only Lactobacillus adjunct strain that attained a more elevated population with AM2 than with IL416 starter; furthermore, AM2 strain survival was also improved in the cheese product.

\subsection{Proteolysis}

Chromatographic profiles of the insoluble cheese fractions at $\mathrm{pH} 4.4$ were essentially the same for all cheeses (data not shown) and the relation $\% \frac{\alpha \mathrm{s} 1-\mathrm{I}}{\alpha \mathrm{s} 1-\mathrm{I}+\alpha \mathrm{s} 1} \mathrm{did}$ not significantly differ $(P<0.05)$ (Tab. II).

We determined nitrogen content (expressed as $\%$ of total nitrogen) for control and experimental cheeses for both starters IL416 and AM2 at $28 \mathrm{~d}$ of ripening. The results are presented in Figure 3 for the soluble nitrogen content at $\mathrm{pH} 4.4(\mathrm{SN})$ and for the phosphotungstic acid-soluble nitrogen content (PTA-N). For starter IL416, more than half the experimental cheeses showed higher SN levels than control cheeses (without lactobacilli), while SN values were very close to those of the control for other cheeses. SN levels of cheeses made with starter AM2 with and without lactobacilli were very close and did not show the same tendency. For both starter strains, Lb. plantarum 1310 was the adjunct resulting in the highest increment in SN levels. The PTA-N values for control cheeses made with AM2 starter varied more than those made with IL416. The production of PTA-N was enhanced for Lb. plantarum 1310 and 1572 with starter IL416. The effect of lactobacilli adjunct in cheeses manufactured with the AM2 strain was less evident. In some cases control cheeses showed a slightly higher level of PTA-N than experimental ones.

The chromatograms of the $70 \%$ ethanol soluble extracts revealed mainly quantitative differences between miniature control and experimental cheeses for the majority of the tested Lactobacillus strains. These results suggest that the starter strains play a more important role than the lactobacilli adjuncts in the production of peptides soluble in $70 \%$ ethanol (see chromatograms for IL416 and AM2 strains control miniature cheeses, Figs. 4a and 4b). Peptide profiles of control cheeses manufactured with the AM2 strain also showed some quantitative differences (Figs. $4 \mathrm{~b}$ and $4 \mathrm{c}$ ), probably because of the changes in AM2 starter viability. The differences agreed with the variability of PTA-N values for control cheeses manufactured with the AM2 strain. Thus, each experimental cheese had only to be compared with the control cheese manufactured the same day. Miniature cheese manufactured with both starters and $L b$. plantarum 1572 adjunct showed qualitative differences compared with control cheese (without lactobacilli). Miniature cheese manufactured with AM2 

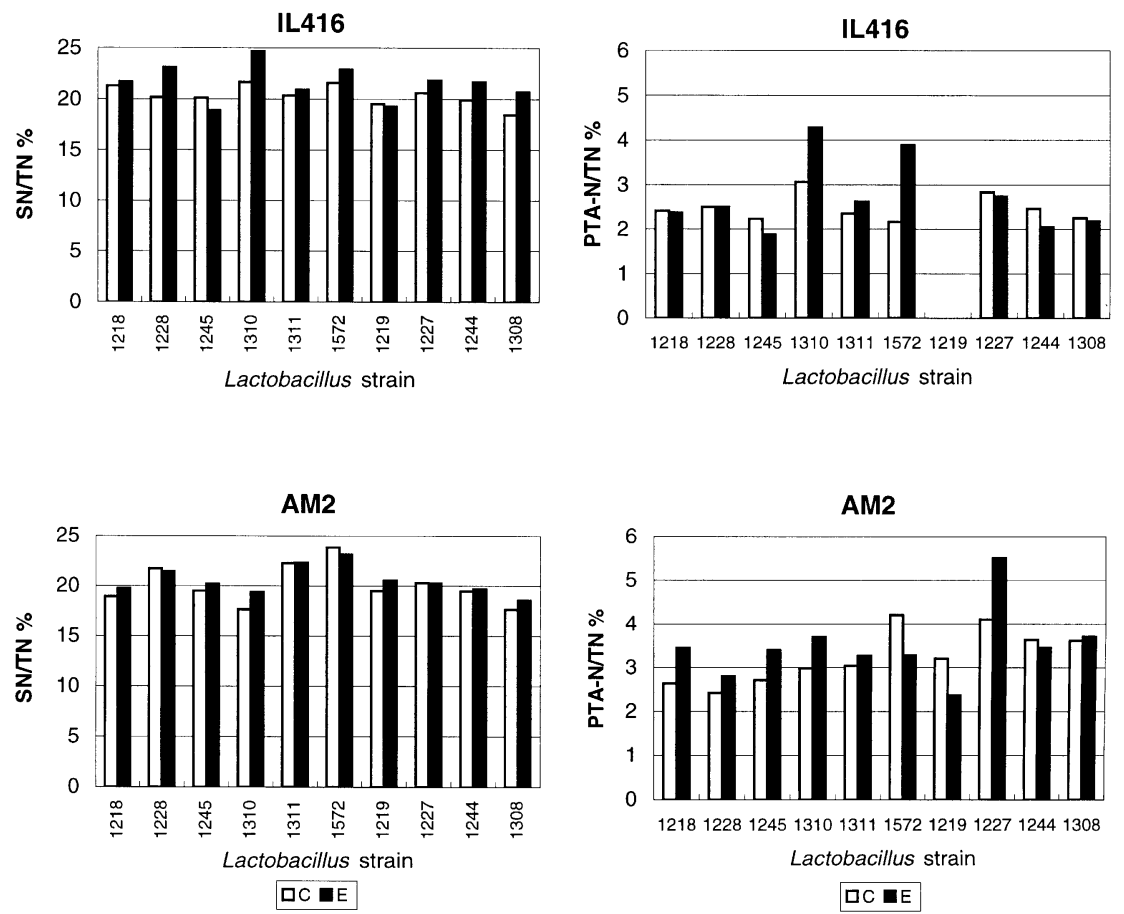

Figure 3. Soluble nitrogen at $\mathrm{pH} 4.4(\mathrm{SN})$ and soluble nitrogen in phosphotungstic acid (PTA-N) expressed as \% of the total nitrogen (TN), for control (C) and experimental (E) miniature cheeses at $28 \mathrm{~d}$ of ripening, made either with starter L. lactis IL416 or starter L. lactis AM2. Numbers under $\mathrm{x}$-axe indicate Lactobacillus strain: $1218 \mathrm{Lb}$. pentosus; 1228, 1245, 1310, 1311 and $1572 \mathrm{Lb}$. plantarum; 1219, 1227, 1244 and 1308 Lb. casei.

starter and adjunct culture of the $L b$. plantarum 1310 strain also differed from control cheese (Fig. 4c).

\section{DISCUSSION}

In the present study, we provide evidence that miniature cheeses as developed here provide a reproducible and simple model for washed-curd cheeses. We also show that the dynamics of starter and lactobacilli adjunct culture populations can vary according to the combination of strains used in cheese-making. The presence of the adjunct culture can also result in altered proteolytic end products, according to the starter and the adjunct strains.

We observed significant differences in starter strain viability according to the strain used; starter IL416 viable cell counts remained constant during ripening, while the AM2 strain population decreased by hundred-fold in control cheeses, as was expected due to autolysis by an activated prophage. In most experimental cheeses (containing lactobacilli), the AM2 starter population remained higher than in control cheeses (without lactobacilli). This effect was verified for six Lactobacillus strains and to our knowledge, has not been reported to date. The opposite effect for a starter of L. lactis subsp. cremoris and a $L b$. casei adjunct was previously reported [2]. The results suggest that lactobacilli culture may have a positive effect on survival of AM2 starter.

Even though differences were found for Lb. casei 1227 and 1308, presumed lysis of 

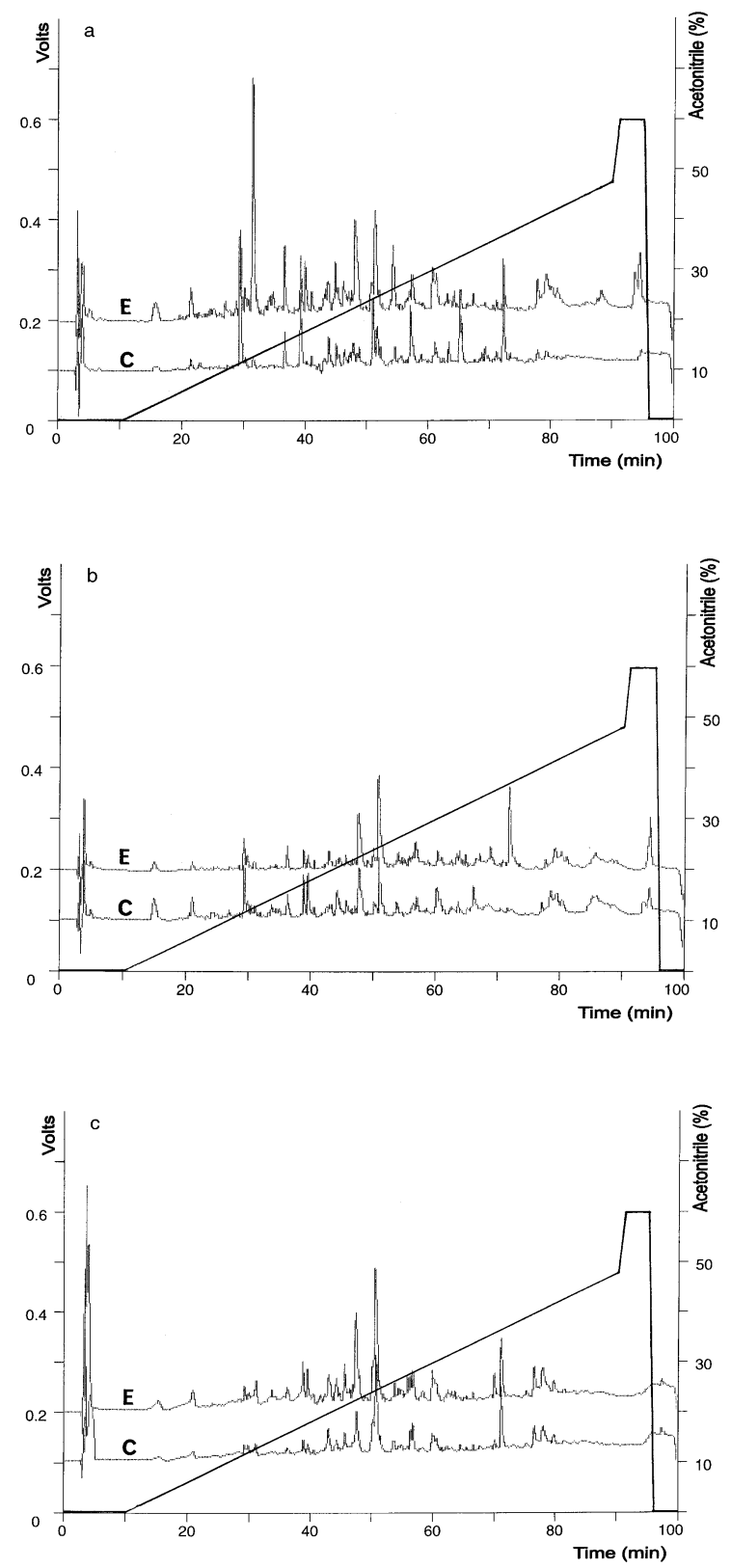

Figure 4. RP-HPLC chromatograms of $70 \%$ (v/v) ethanol soluble extract for miniature cheeses at $28 \mathrm{~d}$ of ripening: (a) L. lactis subsp. lactis IL416 starter, with (E, experimental) and without (C, control) adjunct culture of L. plantarum 1572; (b) L. lactis subsp. cremoris AM2 starter with and without adjunct culture of L. plantarum 1572; (c) L. lactis subsp. cremoris AM2 starter with and without adjunct culture of L. plantarum 1310. 
the AM2 strain did not improve growth of the other Lactobacillus strains (Fig. 2). Thomas [40] demonstrated that lactobacilli are able to grow on lactococcal cell homogenate, so it is generally supposed that lytic starters improve lactobacilli development in cheese. The required concentration is about $1 \mathrm{mg}$ of cells (dry matter) $\mathrm{mL}^{-1}$, which is equivalent to $\sim 10^{9}$ cells. $\mathrm{g}^{-1}$ of cheese, i.e. the complete starter population, conditions we get with a hundred-fold drop in viability. In those studies, carbon, and not nitrogen, appears to be the limiting factor in cheese for the growth of NSLAB. In our cheeses, lactobacilli were added to cheesemaking milk where they can utilise lactose during the first stages of cheese-making, thus possibly abolishing the need for added nutrients provided by lysis of the starter. Lane et al. [20] reported similar results for four types of starter, among them the AM2 strain.

Primary proteolysis was similar for all control and experimental cheeses, showing that lactobacilli did not participate in breakdown of intact caseins in situ. Lane and Fox [19] found differences in primary proteolysis between cheeses prepared with and without a lactobacilli adjunct, and using glucono-delta-lactone to acidify the medium instead of LAB starter culture. In our study, as in others where milk was acidified by a LAB starter, such a difference was not detected [19, 23, 25, 37]. The similarity of $\% \frac{\alpha \mathrm{s} 1-\mathrm{I}}{\alpha \mathrm{s} 1-\mathrm{I}+\alpha \mathrm{s} 1}$ values for experimental and control cheeses also confirmed the reproducibility of miniature cheeses, as it depends on chymosin activity and therefore on water activity, $\mathrm{pH}$ and cheese composition [8]. We conclude that the tested Lactobacillus strains do not possess proteases able to hydrolyse entire caseins in the present experimental conditions.

Secondary proteolysis products were different for control and experimental cheeses. Several authors have reported that lactobacilli adjuncts increased the total amount of free amino acids (FAA) in Cheddar cheese
$[17,24,25,34]$. In our model, the level of PTA-N, which is an index of total FAA [1], was greatest for experimental cheeses manufactured with starter IL416 and adjunct cultures of $L$ b. plantarum 1310 and 1572. Differences in secondary proteolysis for these cheeses were also mirrored in peptide profiles obtained by ethanol soluble extract RP-HPLC. The level of PTA-N was higher in several control cheeses manufactured with the AM2 starter than in the corresponding experimental cheeses (containing lactobacilli). That may be due to greater viability of AM2 starter in experimental cheeses and a consequent reduction in amounts of released starter peptidases. On the contrary, lactobacilli addition may improve PTA-N production. In this case, both contrary effects may be involved, so that some experimental cheeses - notably those with $L b$. casei 1227 - had greater PTA-N levels than control.

\section{ACKNOWLEDGMENTS}

The authors wish to thank A. Gruss for critical reading of the manuscript.

\section{REFERENCES}

[1] Ardö Y., Evaluating proteolysis by analysing the $\mathrm{N}$ content of cheese fractions, in: Chemical methods for evaluating proteolysis in cheese maturation, Bull. Int. Dairy Fed. 337 (1999) 4-9.

[2] Broome M.C., Krause D.A., Hickey M.H., The use of non starter lactobacilli in Cheddar cheese manufacture, Aust. J. Dairy Technol. 45 (1990) 67-73.

[3] Chapot-Chartier M.-P., Deniel C., Rousseau M., Vassal L., Gripon J.C., Autolysis of two strains of Lactoccocus lactis during cheese ripening, Int. Dairy J. 4 (1994) 251-269.

[4] Choisy C., Desmazeaud M., Gripon J.-C., Lamberet G., Lenoir J., La biochimie de l'affinage, in: Eck A., Gillis J.-C. (Eds.), Le Fromage, Lavoisier, Paris, 1997, pp. 86-161.

[5] Cluzel J.P., Chopin A., Ehrlich S.D., Chopin M.C., Phage abortive infection mechanism from Lactoccocus lactis subsp. lactis, expression of which is mediated by an 
Iso-ISS1 element, Appl. Environ. Microbiol. 57 (1991) 3547-3551.

[6] Corsetti A., Gobetti M., Smacchi E., De Angelis M., Rossi J., Accelerated ripening of Pecorino Umbro cheese, J. Dairy Res. 65 (1998) 631-642.

[7] Crow V.L., Coolbear T., Goparl P.K., Martley F.G., McKay L.L., Riepe H., The role of autolysis of lactic acid bacteria in the ripening of cheese, Int. Dairy J. 5 (1995) 855-875.

[8] de Jong L., The influence of the moisture content on the consistency and protein breakdown of cheese, Neth. Milk Dairy J. 32 (1978) 1-14.

[9] de Man J.C., Rogosa M., Sharpe M.E., A medium for the cultivation of lactobacilli, J. Appl. Bacteriol. 23 (1960) 130-135.

[10] Desmazeaud M.J., Gripon J.-C., General mechanism of protein breakdown during cheese ripening, Milchwissenschaft 32 (1977) 731-734.

[11] Fox P.F., McSweeney P.L.H., Lynch C.M., Significance of non-starter lactic acid bacteria in Cheddar cheese, Aust. J. Dairy Technol. 53 (1998) 83-89.

[12] Gripon J.-C., Desmazeaud M.J., Le Bars D., Bergère J.L., Étude du rôle des microorganismes et des enzymes au cours de la maturation des fromages. II. - Influence de la présure commerciale, Lait 55 (1975) 502-516.

[13] Hynes E., Ogier J.-C., Delacroix-Buchet A., Protocol for the manufacture of miniature washed-curd cheeses under controlled microbiological conditions, Int. Dairy J. 10 (2000) 733-737.

[14] Hynes E., Ogier J.-C., Delacroix-Buchet A., Proteolysis during ripening of miniature washed-curd cheeses manufactured with different strains of starter bacteria and Lactobacillus plantarum adjunct culture, Int. Dairy J. 11 (2001) 587-597.

[15] IDF, Determination of nitrogen content, Standard 20B, Int. Dairy Fed., Brussels, Belgium, 1993.

[16] Kawabata S., Vassal L., Le Bars D., Cesselin B., Nardi M., Gripon J.-C., Chapot-Chartier M.P., Phage induced lysis of Lactoccocus lactis during cheese ripening and its impact on proteolysis, Lait 77 (1997) 229-239.

[17] Kleter G., The ripening of Gouda cheese made under strictly aseptic conditions. 2 . The comparison of the activity of different starters and the influence of certain Lactobacillus strains, Neth. Milk Dairy J. 31 (1977) 177-187.
[18] Kuchroo C.N., Fox P.F., Soluble nitrogen in Cheddar cheese: comparison of extraction procedures, Milchwissenschaft 37 (1982) 331-335.

[19] Lane C.N., Fox P.F., Contribution of starter and adjunct lactobacilli to proteolysis in Cheddar cheese during ripening, Int. Dairy J. 6 (1996) 715-728.

[20] Lane C.N., Fox P.F., Walsh E.M., Folkertsma B., McSweeney P.L.H., Effect of compositional and environmental factors on the growth of indigenous non starter lactic acid bacteria in Cheddar cheese, Lait 77 (1997) 561-573.

[21] Lee B.H., Laleye L.C., Simard R.E., Holley R.A., Emmons D.B., Giroux R.N., Influence of homo-fermentative lactobacilli on physicochemical and sensory properties of Cheddar cheese, J. Food. Sci. 55 (1990) 386-390.

[22] Lepeuple A.-S., Vassal L., Cesselin B., Delacroix-Buchet A., Gripon J.-C., ChapotChartier M.-P., Involvement of a prophage in the lysis of Lactococcus lactis subsp. cremoris AM2 during cheese ripening, Int. Dairy J. 8 (1998) 667-674.

[23] Lynch C.M., McSweeney P.L.H., Fox P.F., Cogan T.M., Drinan F.D., Manufacture of Cheddar cheese with and without adjunct lactobacilli under controlled microbiological conditions, Int. Dairy J. 6 (1996) 851-867.

[24] Lynch C.M., McSweeney P.L.H., Fox P.F., Cogan T.M., Drinan F.D., Contribution of starter lactococci and non-starter lactobacilli to proteolysis in Cheddar cheese with a controlled microflora, Lait 77 (1997) 441-459.

[25] Lynch C.M., Muir D.D., Banks J.M., McSweeney P.L.H., Fox P.F., Influence of adjunct cultures of Lactobacillus paracasei ssp. paracasei or Lactobacillus plantarum on Cheddar cheese ripening, J. Dairy Sci. 82 (1999) 1618-1628.

[26] Mabbit L.A., Zielinska M., Acetate agar for isolation of lactobacilli, J. Appl. Bacteriol. 19 (1956) 95-101.

[27] Martley F.G., Crow V.L., Interaction between nonstarter microorganisms during cheese manufacture and ripening, Int. Dairy J. 3 (1993) 461-483.

[28] McSweeney P.L.H., Sousa M.J., Biochemical pathways for the production of flavour compounds in cheeses during ripening: a review, Lait 80 (2000) 293-324.

[29] McSweeney P.L.H., Fox P.F., Lucey J.A., Kordan K.N., Cogan T.M., Contribution of the indigenous microflora to the maturation of Cheddar cheese, Int. Dairy J. 3 (1993) 613-634. 
[30] McSweeney P.L.H., Walsh E.M., Fox P.F., Cogan T.M., Drinan F.D., Castelo-Gonzalez M., A procedure for the manufacture of Cheddar cheese under controlled bacteriological conditions and the effect of adjunct lactobacilli on cheese quality, Irish J. Agric. Food Res. 33 (1994) 183-192.

[31] Naylor J., Sharpe M.E., Lactobacilli in Cheddar cheese. III. The source of lactobacilli in cheese, J. Dairy Res. 25 (1958) 431-438.

[32] Perreard E., Fromagerie d'emmental. Flore lactique «secondaire » ou d'affinage, Rev. Lait. Fr. (1998) 12.

[33] Peterson S.D., Marshall R.T., Nonstarter lactobacilli in Cheddar cheese: a review, J. Dairy Sci. 73 (1990) 1395-1410.

[34] Puchades R., Lemieux L., Simard R.E., Evolution of free amino acids during the ripening of Cheddar cheese containing added lactobacilli strains, J. Food Sci. 54 (1989) 885-888.

[35] Ramet J.-P., Technologie comparée des différents types de caillé, in: Eck A., Gillis J.-C. (Eds.), Le Fromage, Lavoisier, Paris, 1997, pp. 334-364.

[36] Shakeel-Ur-Rehman, McSweeney P.L.H., Fox P.F., Protocol for the manufacture of miniature cheeses, Lait 78 (1998) 607-620.

[37] Shakeel-Ur-Rehman, Banks J.M., McSweeney P.L.H., Fox P.F., Effect of ripening temperature on the growth and significance of non-starter acid bacteria in Cheddar cheese made from raw or pasteurised milk, Int. Dairy J. 10 (2000) 45-53.

[38] Tailliez P., Quénée P., Chopin A., Estimation de la diversité parmi les souches de la collection CNRZ: application de la RAPD à un groupe de lactobacilles, Lait 76 (1996) 147-158.

[39] Terzaghi B.E., Sandine W.E., Improved media for lactic streptococci and their bacteriophages, Appl. Microbiol. 29 (1975) 807-813.

[40] Thomas T., Cannibalism among bacteria found in cheese, N. Z. J. Dairy Sci. Technol. 22 (1987) 215-219.

[41] Trépanier G., Simard R.E., Lee B.H., Lactic acid bacteria relation to accelerated maturation of Cheddar cheese, J. Food Sci. 56 (1991) 1238-1254.

[42] Turner K.W., Lawrence R.C., Lelievre J., A microbiological specification for milk for aseptic cheesemaking, N. Z. J. Dairy Sci. Technol. 21 (1986) 249-254.

[43] Urbach G., Relations between cheese flavour and chemical composition, Int. Dairy J. 3 (1993) 389-422.

[44] Visser S., Slangen K.J., Rollema H.S., Phenotyping of bovine milk proteins by reversed-phase high performance liquid chromatography, J. Chromatogr. 548 (1991) 361-370. 